Rika Marianti ${ }^{1}$

Nurmalina $^{2}$

Vigi Indah Permatha

Sari $^{3}$

\section{PENINGKATAN KETERAMPILAN BERBICARA MENGGUNAKAN MEDIA GAMBAR PADA SISWA KELAS V SD NEGERI 007 PULAU LAWAS}

\begin{abstract}
Abstrak
Penelitian ini dilatar belakangi oleh rendahnya keterampilan berbicara siswa pada pembelajaran tematik di kelas V SD Negeri 007 Pulau Lawas. Metode penelitian ini adalah Penelitian Tindakan Kelas (PTK) yang dilaksanakan dalam dua siklus. Setiap siklus terdiri dari dua pertemuan. Subjek penelitian ini siswa kelas V yang berjumlah 14 orang, dengan jumlah lakilaki 6 orang, dan siswa perempuan berjumlah 8 orang siswa. Teknik pengumpulan data berupa dokumentasi, observasi, dan tes. Hasil penelitian ini dapat disimpulkan bahwa media gambar dapat meningkatkan keterampilan berbicara siswa pada kelas V SD Negeri 007 Pulau Lawas. Pada siklus I hasil keterampilan berbicara siswa tergolong kurang dengan persentase $50 \%$. Selanjutnya pada siklus II dengan persentase $92.85 \%$ dengan katagori sangat baik. Dengan demikian dapat disimpulkan menggunakan media gambar dapat meningkatkan keterampilan berbicara siswa kelas V SD Negeri 007 Pulau Lawas Tahun ajaran 2020/2021.
\end{abstract}

Kata Kunci: Peningkatan, Keterampilan Berbicara, Media Gambar

\begin{abstract}
This research was motivated by the low speaking skills of students in thematic learning in class V SD Negeri 007 Pulau Lawas. This research method is Classroom Action Research (PTK) which is carried out in two cycles. Each cycle consists of two meetings. The subjects of this research were 14 grade V students, 6 male students, and 8 female students. Data collection techniques in the form of documentation, observation, and tests. The results of this study can be concluded that the media image can improve the speaking skills of students in class V SD Negeri 007 Pulau Lawas. In the first cycle the results of the students' speaking skills were classified as less with a percentage of $50 \%$. Furthermore, in the second cycle with a percentage of $92.85 \%$ in the very good category. Thus it can be concluded that using image media can improve speaking skills of fifth grade students of SD Negeri 007 Pulau Lawas for the 2020/2021 academic year.
\end{abstract}

Keywords: Improvement, Speaking Skills, Image Media

\footnotetext{
${ }^{1}$ Pendidikan Guru Sekolah Dasar, Fakultas Ilmu Pendidikan, Universitas Pahlawan Tuanku Tambusai

Alamatemail rikaamarianti17@gmail.com
} 


\section{PENDAHULUAN}

Pendidikan merupakan salah satu sarana yang digunakan pemerintah untuk mewujudkan cita-cita luhur bangsa, yaitu mencerdaskan kehidupan masyarakat Indonesia. Untuk menunjang tercapainya cita-cita tersebut, pemerintah membuat kebijakan terkait pelaksanaan pendidikan di Indonesia. Di indonesia, pendidikan sendiri memiliki tujuan utama yang termuat dalam Pembukaan UUD 1945 yaitu mencerdaskan kehidupan bangsa. Selanjutnya pengertian pendidikan lebih lanjut dijelaskan dalam Undang-Undang No. 20 Tahun 2003 pasal 1 tentang Sistem Pendidikan Nasional disebutkan bahwa:

Pendidikan adalah sebagai usaha sadar dan terencana untuk mewujudkan suasana belajar dan proses pembelajaran agar siswa dapat secara aktif mengembangkan potensi dirinya untuk memiliki kekuatan spiritual keagamaan, pengendalian diri, kepribadian, kecerdasan, akhlak mulia, serta keterampilan yang diperlukan dirinya, masyarakat, bangsa, dan negara. Dalam rangka mewujudkan visi dan menjalankan misi pendidikan nasional yang tercantum dalam UU No. 20 Tahun 2003, diperlukan suatu pedoman dalam penyelenggaraan pendidikan atau yang disebut dengan kurikulum. Undang-Undang Sisdiknas No. 20 Tahun 2003 menjelaskan bahwa kurikulum adalah seperangkat rencana dan pengaturan mengenai tujuan, isi, dan bahan pelajaran serta cara yang digunakan sebagai pedoman penyelenggaraan kegiatan pembelajaran untuk mencapai tujuan pendidikan tertentu. Pada tahun 2013 kurikulum tingkat sekolah dasar mengalami perubahan dari kurikulum KTSP menuju kurikulum 2013. Salah satu mata pelajaran yang selalu ada dalam kurikulum pendidikan yaitu Bahasa Indonesia.

Pendidikan Bahasa Indonesia merupakan salah satu aspek penting yang perlu diajarkan kepada para siswa di sekolah. Mata pelajaran ini diberikan sejak masih di bangku SD karena dari situ diharapkan siswa mampu menguasai, memahami dan dapat mengimplementasikan keterampilan berbahasa, seperti membaca, menyimak, menulis, dan berbicara. Pembelajaran Bahasa Indonesia diarahkan untuk meningkatkan kemampuan siswa untuk berkomunikasi dalam Bahasa Indonesia dengan baik dan benar. Pelajaran bahasa indonesia mencakup komponen kemampuan berbahasa dan kemampuan bersastra yang meliputi aspek mendengarkan, berbicara, membaca, dan menulis (Rizal, 2019: 254).

Keterampilan berbicara adalah salah satu keterampilan berbahasa sebagai kemampuan mengucapkan bunyi-bunyi artikulasi atau kata-kata untuk mengekspresikan, menyatakan serta mengungkapkan pendapat atau pikiran dan perasaan kepada seseorang atau kelompok secara lisan, baik secara berhadapan ataupun dengan jarak jauh. Keterampilan berbicara merupakan suatu aspek yang sangat penting dalam bahasa hal ini juga disampaikan secara khusus oleh Tarigan (2008: 16) yang mengemukakan ''berbicara adalah kemampuan mengucapkan bunyibunyi artikulasi atau kata-kata untuk mengekspresikan, menyatakan serta menyampaikan pikiran, gagasan, dan perasaan'. Keterampilan berbicara yang baik akan mempermudah orang lain atau penerima pesan untuk mengerti dan memahami ide dan gagasan yang ingin disampaikan.

Berdasarkan hasil observasi di kelas dan wawancara dengan guru kelas V SD Negeri 007 Pulau Lawas peneliti menemukan beberapa masalah di sekolah dasar, salah satunya yaitu kemampuan siswa dalam aspek berbicara masih kurang. Kebanyakan siswa malu dan ragu-ragu saat mengungkapkan gagasan dan ide mereka. Siswa juga kurang aktif dalam pembelajaran, siswa sering sekali mengabaikan pertanyaan-pertanyaan yang dilontarkan oleh guru. Pertanyaan-pertanyaan yang diajukan oleh guru sering kali tidak dijawab oleh siswa, sehingga 
guru harus mengulang pertanyaan tersebut beberapa kali dan siswa merasa takut ketika berbicara di depan teman-temannya ataupun di depan kelas. Masalah ini merupakan masalah yang dialami oleh sebagian besar siswa dalam pembelajaran. Siswa seringkali menolak apabila diminta untuk berbicara di depan teman-temannya atau di depan kelas. Siswa lebih memilih untuk berbicara di tempat duduknya masing-masing karena takut salah ketika berbicara di depan kelas. Hal ini terjadi karena siswa kurang berlatih untuk berbicara di depan kelas.

Keterampilan berbicara yang baik dapat menghasilkan suatu komunikasi yang baik pula. Pujiono (2013: 83) menyatakan bahwa berbicara merupakan keterampilan berbahasa yang bertujuan untuk mengungkapkan ide, gagasan, serta perasaan secara lisan sebagai proses komunikasi kepada orang lain. Dengan demikian, apabila seseorang ingin mengungkapkan ide, gagasan maupun perasaanya kepada orang lain maka seseorang ini terlebih dahulu harus melatih dan mengembangkan keterampilan berbicaranya.Guru juga berperan penting untuk meningkatkan keterampilan berbicara siswa. Didalam proses belajar mengajar guru dituntut untuk lebih kreatif dalam menciptakan kondisi dan suasana belajar yang dapat meningkatkan aktivitas belajar siswa (Mufarizuddin, 2017: 29). Mengatasi permasalahan terkait kurangnya keterampilan berbicara pada siswa tersebut, dapat dilakukan melalui salah satu media pembelajaran yaitu menggunakan media gambar. Pada penggunaan media ini guru lebih kreatif dalam menyampaikan materi pembelajaran agar anak tertarik dengan materi pembelajaran yang disampaikan oleh guru (Fauziddin, 2019: 937). Media gambar merupakan salah satu media yang dapat digunakan untuk membantu siswa dalam keterampilan berbicara dengan memperlihatkan gambar siswa dapat memahami dan mengutarakan apa maksud isi gambar tersebut, dan menceritakan maksud dari gambar yang diperlihatkan oleh guru. Media gambar dapat digunakan guru untuk memberikan pengalaman-pengalaman siswa yang sulit didapatkan melalui media langsung. Melalui hasil penelitian yang dilakukkan oleh Emiliana (2013) dalam penelitiannya telah membuktikan bahwa dengan menggunakan media gambar dapat meningkatkan kemampuan berbicara anak di sekolah dasar.

Berdasarkan latar belakang seperti yang dikemukakan diatas, penulis tertarik untuk melakukan kegiatan penelitian dengan judul "Peningkatan Keterampilan Berbicara Menggunakan Media Gambar Pada Siswa Kelas V SD Negeri 007 Pulau Lawas”.

\section{METODE}

Metode penelitian ini adalah Penelitian Tindakan Kelas (PTK). Menurut Arikunto (2014: 58), Penelitian Tindakan Kelas adalah penelitian tindakan yang dilakukan dikelas dengan tujuan memperbaiki/meningkatkan mutu praktik pembelajaran. Penelitian ini direncanakan dengan dilaksanakan ke dalam siklus, dimana jika pada pelaksanaan siklus I, terdapat hambatan dan permasalahan belum dapat diatasi berdasarkan kriteria yang telah ditetapkan, maka penelitian akan dilanjutkan pada siklus berikutnya yaitu siklus II dengan berbagai perbaikan dalam masing-masing tahapan. Setiap siklus terdiri dari empat tahapan yaitu, perencanaan, pelaksanaan, pengamatan, dan refleksi. Subjek penelitian ini adalah siswa kelas V SD Negeri 007 pulau lawas dengan jumlah siswa 14 yang terdiri dari 6 siswa laki-laki dan 8 siswa perempuan.

Teknik pengumpulan data yang digunakan dalam penelitian ini yaitu: Pemerolehan data dalam penelitian ini salah satunya adalah dari hasil observasi. Sudijono (2011: 76-77) mengatakan bahwa: Observasi adalah cara menghimpun bahan-bahan keterangan yang dilakukan dengan mengadakan pengamatan dan pencatatan secara sistematis terhadap fenomena-fenomena yang sedang dijadikan sasaran pengamatan. Observasi digunakan untuk menilai tingkah laku individu atau proses terjadinya suatu kegiatan yang dapat diamati, baik 
dalam situasi yang sebenarnya maupun dalam situasi buatan. Peneliti melakukan pengamatan dengan melihat proses pembelajaran keterampilan berbicara dengan menggunakan media gambar. Dan wawancara dapat diartikan sebagai teknik pengumpulan data dengan menggunakan bahasa baik secara tatap muka ataupun melalui saluran media tertentu.

Instrumen penelitian dalam penelitian ini adalah tes, lembar observasi dan dokumentasi. Tes merupakan instrumen yang sistematis untuk mengukur suatu sampel tingkah laku (Nurgiyantoro, 2013: 7). Tes digunakan untuk mengukur keterampilan berbicara siswa menggunakan media gambar. Untuk tes keterampilan berbicara, digunakan pedoman penilaian keterampilan berbicara. Lembar observasi guru dan lembar observasi siswa. Menurut Sugiyono (2011: 240) dokumentasi merupakan catatan peristiwa yang sudah berlaku. Dokumen dapat berbentuk gambar, tulisan, atau karya-karya monumental dari seseorang. Studi dokumentasi ini sebagai pelengkap dari penggunaan teknik tes dan observasi. Dokumentasi dalam penelitian ini berwujud foto untuk menyaring data siswa ketika mereka berbicara.

Teknik analisis data Teknik analisis yang digunakan dalam menganalisa data kuantitatif yang diperoleh dari tes hasil belajar siswa adalah Ketuntasan belajar individu , Ketuntasan Belajar Klasikal, Keberhasilan Penelitian pada penelitian ini direncanakan akan dilaksanakan dalam dua siklus, apabila secara klasikal pada siklus kedua telah mencapai angka sebesar $80 \%$ (Depdiknas, 2001). Siswa dapat dikatakan berhasil dengan interval $\geq 70$ dengan katagori cukup maka penelitian ini pun dapat dikatakan telah berhasil dan siklus dapat dihentikan. Teknik analisis data kualitatif dalam penelitian ini berupa deskripsi dari hasil pengamatan pembelajaran keterampilan berbicara dan proses pembelajaran menggunakan media gambar.

\section{HASIL DAN PEMBAHASAN}

Deskrisi pratindakan dari hasil observasi langsung yang dilakukan peneliti. Peneliti mendapati keterampilan berbicara siswa belum mencapai kategori yang ditentukan peneliti yaitu 70 dari seluruh siswa dan belum mencapai target yang telah ditentukan $80 \%$ secara klasikal, sehingga peneliti perlu melakukan perbaikan pembelajaran menggunakan media gambar. Untuk meningkatkan keterampilan berbicara siswa. Hasil pratindakan siswa yaitu 35,71\%.

Deskripsi hasil tindakan tiap siklus di lakukan empat kali pertemuan yang mana siklus I dua kali pertemuan dan siklus II dua kali petemuan. Pada siklus I terdapat tahapan yang perlu peneliti lakukan yaitu tahap perencanaan, pelaksanaan, observasi dan refleksi Berdasarkan hasil keterampilan berbicara siswa pada siklus I mengalami peningkatan yaitu dari 14 siswa yang tuntas yaitu 7 orang siswa dengan ketuntasan klasikal $50 \%$.

Pada siklus I ini pelaksanaan keterampilan berbicara siswa sudah muncul perkembangannya dibandingkan dengan pratindakan, terlihat pada saat siswa berbicara di depan kelas mulai meningkat, beberapa siswa sudah memperhatikan indikator-indikator keterampilan berbicara. Sebagian Siswa sudah tidak malu-malu lagi untuk tampil di depan kelas dan berbicara. Namun pada pertemuan ini siswa masih ada yang bermain dan tidak memperhatikan guru atau pun saat temannya tampil. Namun guru tetap memberikan penghargaan berupa pujian kepada siswa yang berani berbicara tentang gambar yang diberikan oleh guru, dan terus memotivasi siswa supaya lebih bersemangat dan belajar lagi pada pertemuan yang akan datang.

Menggunakan media gambar, dapat dilihat bahwa nilai keterampilan berbicara siswa kelas V SD Negeri 007 Pulau Lawas pada tindakan siklus I mengalami peningkatan apabila dibandingkan dengan nilai pratindakan. Peningkatan keterampilan berbicara pada siklus I sebesar $50 \%$ secara klasikal sedangkan nilai pratindakan siswa hanya $35.71 \%$ secara klasikal. Maka dari hasil yang didapatkan pada siklus I belum mencapai ketuntasan yang diinginkan oleh peneliti yaitu masik kategori kurang dan belum mencapai target $80 \%$. Oleh sebab itu peneliti 
melakukan penelitian lanjutan pada siklus II untuk memperbaiki kekurangan pada siklus I.

Data hasil keterampilan berbicara siswa pada kelas V SD Negeri 007 Pulau lawas dengan menggunakan media gambar pada siklus II mendapatkan peningkatan yang mana pada siklus II mendapatkan hasil keterampilan berbicara siswa yang tuntas 13 orang siswa dengan ketuntasan klasikal $92,85 \%$ dan siswa yang tidak tuntas 1 orang siswa 7,14\%. Perbaikan keterampilan berbicara siswa menggunakan media gambar telah mencapai target peneliti yaitu kategori cukup dengan nilai 70 serta sudah mencapai ketuntasan klasikal $80 \%$ sesuai dengan yang disampaikan (Dekdiknas, 2001).

Berdasarkan hasil yang telah diperoleh maka dapat disimpulkan keterampilan berbicara menggunakan media gambar dapat berbicara siswa SD Negeri 007 pulau lawas. Hasil peningkatan keterampilan berbicara siswa antar siklus, dapat dilihat dalam diagram 1 berikut:

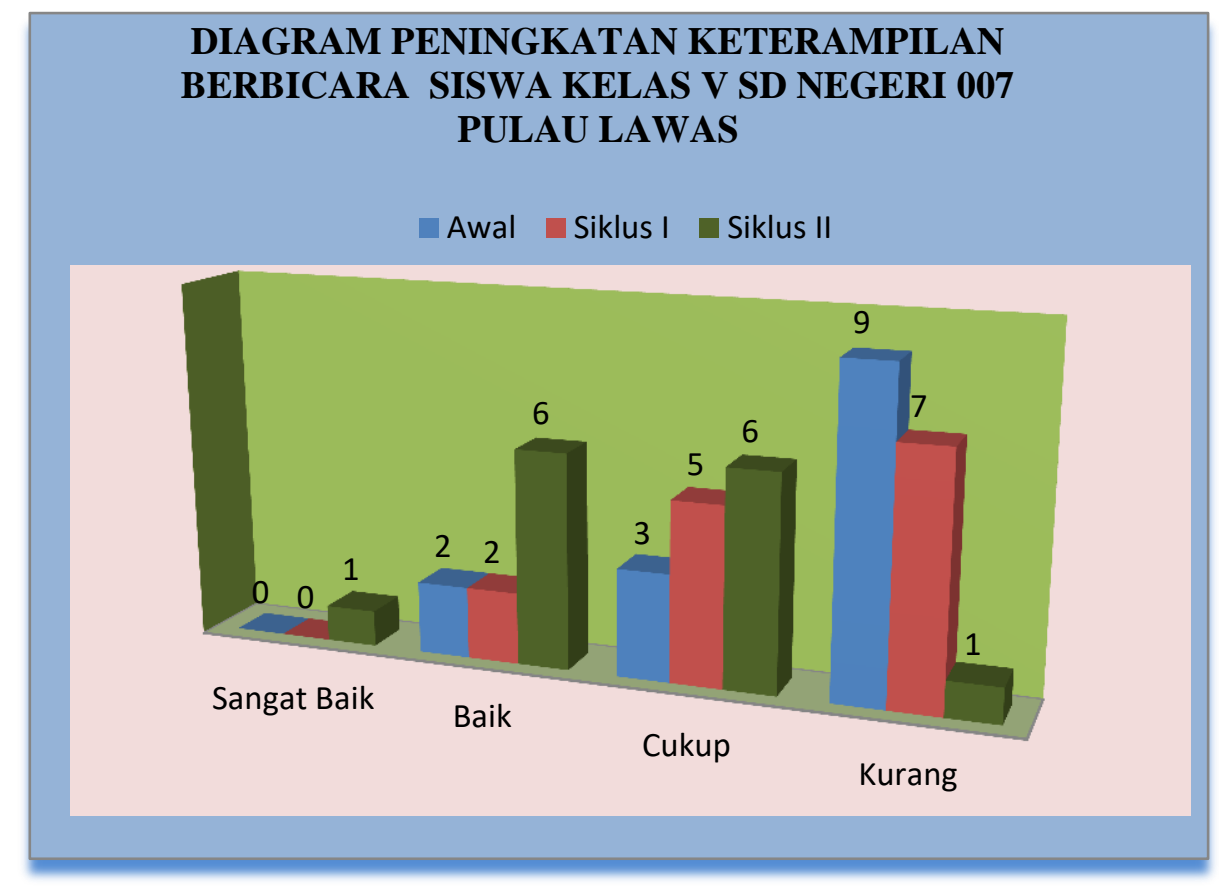

\section{Diagram 1. Peningkatan Keterampilan Berbicara Siswa Pada Pratindakan, Siklus I, Siklus II}

Berdasarkan diagram hasil perolehan keterampilan berbicara siswa pada awal tindakan dengan persentase $35.71 \%$ menigkat pada siklus I dengan persentase $50 \%$. Pada siklus II mengalami peningkatan jika dibandingkan dengan siklus I. Hasil keterampilan berbicara siswa pada siklus II secara keseluruhan sebesar $92.85 \%$ yang artinya keterampilan berbicara siswa sudah mencapai dari kriteria yang ditetapkan yaitu $80 \%$.

\section{SIMPULAN}

Penelitian ini yang dilakukan di SD Negeri 007 pulau lawas berdasarkan hasil penelitian dan pembahasan yang telah dilasanakan dengan dua siklus maka dapat disimpulkan keterampilan berbicara siswa kelas V SD Negeri 007 pulau lawas pada semester ganjil 2020/2021, dapat ditingkatkan dengan menggunakan media gambar yang telah berjalan sesuai dengan yang direncanakan dan dilaksanakan dengan semaksimal mungkin baik dari pihak peneliti, observer dan sekolah. Hasil keterampilan berbicara siswa pada siklus I mencapai 
ketuntasan klasikal yaitu 50\%, kemudian pada siklus II ketuntasan meningkat menjadi 92,85\%. Dari hasil setiap siklus dapat diperoleh kesimpulan bahwa untuk peningkatan keterampila berbicara siswa pada siswa kelas V SD Negeri 007 pulau lawas dapat menggunakan media gambar dalam proses pembelajaran siswa. Dengan menggunakan media gambar pembelajaran siswa menjadi menyenangkan sehingga siswa semangat untuk belajar dan juga dapat membantu siswa agar lebih mudah untuk berbicara dengan menggunakan media gambar.

Bagi guru dapat menggunakan media gambar sebagai alternatif dalam pembelajaran karena telah terbukti dapat meningkatkan keterampilan berbicara pada siswa kelas V SD Negeri 07 pulau lawas. Bagi penelitian selanjutnya dapat melengkapi penelitian ini, yaitu dengan variasi yang lebih baik, dan menarik, sehingga keterampilan berbicara siswa dapat lebih optimal.

\section{DAFTAR PUSTAKA}

Arikunto, Suharsimi. 2014. Penelitian Tindakan Kelas. Jakarta: Bumi Aksara.

Arsyad, (2014). Pembinaan Kemampuan Berbicara Bahasa Indonesia. Jakarta : Erlangga.

Depdiknas. (2001). Pembelajaran Efektif. Depsiknas Jakarta.

Emiliana. (2013). Peningkatan Kemampuan Berbicara Menggunakan Media Gambar Di Kelas $V$ SDN 04 hulu Sungai Ketapang. Fakultas Keguruan Dan Ilmu Pendidikan Universitas Tanjungpura Pontianak .

Fauziddin. (2019). Peningkatan Motivasi Belajar Siswa Menggunakan Media Audio Visual Pada Pembelajaran Bahasa Indonesia. Jurnal Pendidikan Tambusai. Volume 3 Nomor. 936-945

Nurgiyantoro, B. (2013). Penilaian Pembelajaran Bahasa Berbasis Kompetensi. Yogyakarta: BPFE.

Mufarizuddin. (2017). Meningkatkan Aktivitas Belajar Siswa Dengan Menggunakan Alat Peraga Pada Pembelajaran IPA Dikelas V SD. Jurnal Sekolah (JS). Volume 1 Nomor 2. 28-32

Pujiono. S . (2013). Terampil Menulis: Cara Mudah dan Praktis dalam Menulis. Yogyakarta: Graha Ilmu.

Rizal, M. S. (2019). Peningkatan Kemampuan Membaca Permulaan Dengan Menggunakan Metode Strujtural Analitik Sintetik (Sas) Terhadap Siswa Kelas 1 SDN 81 Pekanbaru. Jurnal Review Pendidikan Dan Pengajaran (JRPP). Volume 2 Nomor 2.

Sudijono. A. (2011). Pengantar Evaluasi Pendidikan. Jakarta: Rajawali Pers.

Sugiyono. (2011). Metode Penelitian Kunatitatif, Kualitatif, dan R \& D. Bandung: Alfabeta CV. Tarigan, H.G. (2008). Berbicara Sebagai Suatu Keterampilan Berbahasa. Bandung: CV. Angkasa. 